\title{
Numerical simulations of onshore transport of larvae and detritus to a steep pocket beach
}

\author{
Atsushi G. Fujimura ${ }^{1,2, *}$, Ad J. H. M. Reniers ${ }^{2,3}$, Claire B. Paris ${ }^{2}$, Alan L. Shanks ${ }^{4}$, \\ Jamie H. MacMahan ${ }^{5}$, Steven G. Morgan ${ }^{6}$ \\ ${ }^{1}$ Marine Laboratory, University of Guam, Mangilao, Guam 96923, USA \\ ${ }^{2}$ Rosenstiel School of Marine and Atmospheric Science, University of Miami, 4600 Rickenbacker Causeway, Miami, FL 33149, \\ USA \\ ${ }^{3}$ Department of Hydraulic Engineering, Delft University of Technology, Stevinweg 1, 2628 CN, Delft, The Netherlands \\ ${ }^{4}$ Oregon Institute of Marine Biology, University of Oregon, 63466 Boat Basin Road, Charleston, OR 97420, USA \\ ${ }^{5}$ Department of Oceanography, Naval Postgraduate School, 1 University Way, Monterey, CA 93943, USA \\ ${ }^{6}$ Bodega Marine Laboratory, University of California, Davis, 2099 Westside Road, Bodega Bay, CA 94923, USA
}

\begin{abstract}
Larvae of intertidal invertebrates need to cross the surf zone to settle in their adult habitat. Onshore transport of invertebrate larvae and detritus at a steep beach was simulated with a biophysical larval tracking model. Hydrodynamic model calculations were performed for $24 \mathrm{~h}$ after a $24 \mathrm{~h}$ spin-up stage with bathymetry and averaged wave data obtained during the summer of 2011 at Carmel River State Beach, California, and with and without onshore wind. The physical model output was then transferred to a Lagrangian larval tracking model using several types of particles representing larvae. A southward alongshore current controlled particle distribution in the middle and north of the domain. At the southern shore, negatively buoyant particles were trapped by eddies generated between the alongshore current and shore, while positively buoyant particles were carried onshore by wind-driven surface currents. The concentration of modeled detritus in the surf zone was positively correlated with that of negatively buoyant larvae. Additionally, the concentrations of detritus and competent larvae within the surf zone were negatively correlated with wave height, consistent with the observations of the accompanying field study. Some eddies contributed to forming high particle concentration patches by trapping them in the surf zone. More small eddies were generated closer to the shore with smaller waves, leading to high larval and detrital concentration in the surf zone. As waves increased in size, fewer and larger eddies formed, predominantly outside the surf zone, and consequently fewer larvae and detritus particles entered or stayed in the surf zone.
\end{abstract}

KEY WORDS: Larval transport · Biophysical model · Surf zone $\cdot$ Steep beach · Competent larvae · Detritus $\cdot$ Eddies

\section{INTRODUCTION}

Larvae of many intertidal invertebrates develop offshore and migrate back to the shore at the end of their development period. The surf zone is the last stage of the migration of intertidal invertebrate larvae, but the mechanism of larval onshore delivery

*Corresponding author: fujimuraa@triton.uog.edu across the surf zone, which acts as a semi-permeable barrier to larval recruitment (Rilov et al. 2008, Shanks et al. 2010), is not well understood. Most invertebrate larvae are slow swimmers (Mileikovsky 1973, Chia et al. 1984) that depend on water currents and other physical forcing during their onshore migration; however, at spatial scales smaller than the

(C) The authors 2017. Open Access under Creative Commons by Attribution Licence. Use, distribution and reproduction are unrestricted. Authors and original publication must be credited. 
order of $10 \mathrm{~m}[O(10) \mathrm{m}]$, swimming and sinking behavior of larvae may also need to be taken into account (Butman 1987).

Vertical migration of larvae interacts with crossshelf currents controlled by various mechanisms (e.g. upwelling/downwelling, tidal currents, wind-driven currents) that affect horizontal distributions of larvae and may facilitate larval transport to shore for settlement (Queiroga \& Blanton 2004). Larvae of some intertidal invertebrate species behave as passive particles and sink to the bottom in turbulence (Denny \& Shibata 1989, Butman 1990, Fuchs et al. 2004, Roy et al. 2012); oyster larvae (Crassostrea virginica) even actively move downward in turbulence (Fuchs et al. 2013). These behaviors could enhance settlement success when bottom currents are directed shoreward. Moreover, a numerical model of delivery of larvae to the surf zone on a mildly sloping beach showed that vertical movement of larvae driven by buoyancy and a turbulent-dependent sinking behavior may be important for onshore larval transport (Fujimura et al. 2014).

In addition to the vertical motion of larvae as a critical biological forcing, Fujimura et al. (2014) demonstrated that 2 physical processes were essential for successful larval delivery to the surf zone: Stokes drift and bottom boundary layer streaming. Their study showed that Stokes drift (Stokes 1847), the wave-related time-averaged volumetric transport in the direction of wave propagation, is necessary to transport larvae toward the surf zone effectively. Socalled streaming is the water flow in the direction of wave propagation induced by wave stress in the wave bottom boundary layer (Longuet-Higgins 1953). Although streaming velocity values are low $[O(1) \mathrm{cm}$ $\left.\mathrm{s}^{-1}\right]$, streaming can enhance delivery of bottomdwelling larvae into the surf zone. On the other hand, offshore currents preventing onshore larval migration occur near the surface when wind forcing is zero and near the bottom during an onshore wind event.

Processes of larval delivery to shore vary with beach morphology. Fujimura et al. (2014) identified possible mechanisms of larval transport at a gently sloping beach with rip channels. Here we examine the effects of physical, biological, and morphological factors on the delivery of competent larvae (ready to settle) to the surf zone of the steep pocket beach at Carmel River State Beach (CRSB) by using a biophysical numerical model based on Fujimura et al. (2014). Because of its steepness and alongshore variability, the mechanism of larval transport at CRSB should differ from that of the gently sloping ripchanneled beach as shown in Morgan et al. (2016). In terms of beach slopes, recruitment is higher at gently sloping beaches than at steep beaches (Shanks et al. 2010, 2017), which is probably due to differential cross-shore water exchange. Studies on surf zone hydrodynamics at gently sloping beaches have been performed by models (e.g. Reniers et al. 2010) and field measurements (e.g. MacMahan et al. 2010); however, hydrodynamics and associated cross-shore exchange at steep beaches are poorly understood. This modeling study includes some characteristics of waves and currents at the steep beach with mild alongshore variability.

An accompanying field study (Shanks et al. 2015) showed that competent larvae and detritus were at times more concentrated in the surf zone than offshore, while holoplankton and precompetent larvae were found at much lower concentrations in the surf zone than offshore. Since the concentration of detritus was significantly correlated with concentrations of competent larvae in the surf zone at CRSB, there is probably a common mechanism of onshore delivery of detritus and competent larvae at this beach, and therefore transport of detritus was simulated here as well. Shanks et al. (2015) also revealed that concentrations of detritus and competent larvae within the surf zone were negatively correlated with wave height, and so we also examine the effect of wave height on these concentrations.

\section{MATERIALS AND METHODS}

\section{Field data}

Physical data were collected at CRSB $\left(36^{\circ} 32^{\prime} 18^{\prime \prime} \mathrm{N}\right.$, $\left.121^{\circ} 55^{\prime} 43^{\prime \prime} \mathrm{W}\right)$, California, in June and July 2011 (Fig. 1A). The surf zone at CRSB is very narrow $[O(10) \mathrm{m}]$. Acoustic Doppler current profilers (ADCPs) were deployed to obtain wave height, period, and angle data for model input. Bathymetric data used for the model grid were collected with a personal watercraft and kayak equipped with an echo sounder and a GPS. The dry beach and intertidal areas were mapped by walking with a GPS backpack. The small river mouth behind the beach was closed most of the time during the survey period, and the presence of the ephemeral river was ignored in the model.

\section{Hydrodynamic model}

For the 3-dimensional hydrodynamic model simulations of the nearshore, we used the computational 

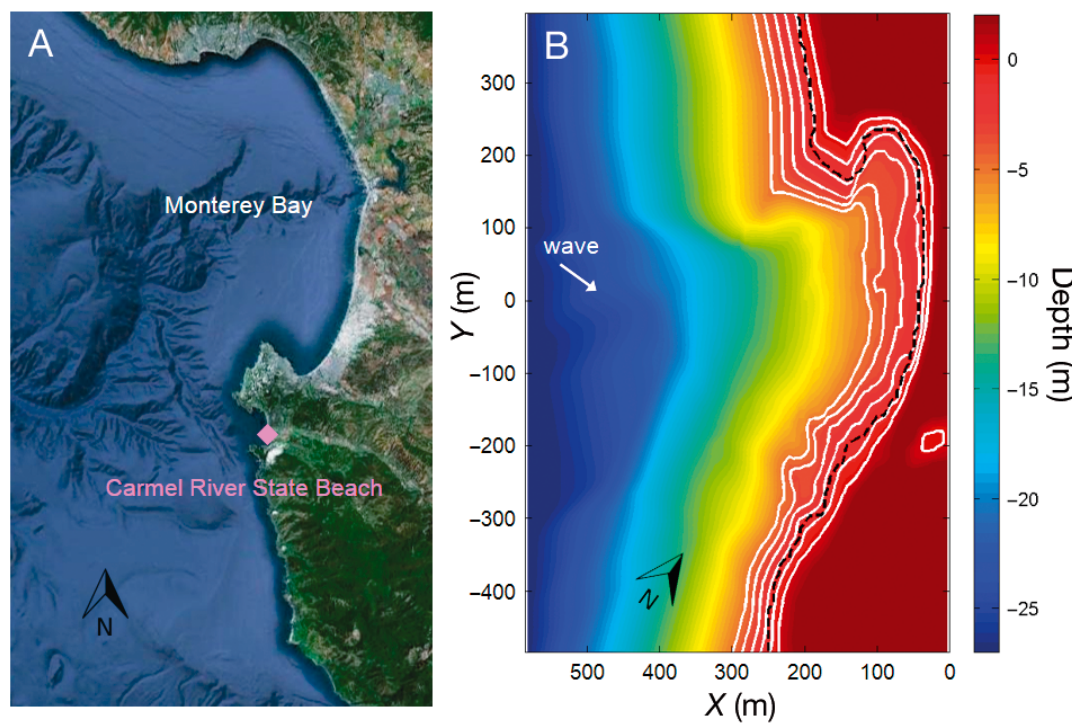

Fig. 1. (A) Location of Carmel River State Beach (CRSB) (credit: Google Earth). (B) Bathymetry at CRSB in cross-shore $(X)$ and alongshore $(Y)$ coordinates. White bottom contour lines are in $1 \mathrm{~m}$ increments from depth of $0 \mathrm{~m}$ (shoreline) to $5 \mathrm{~m}$. Black dashed line is the approximate surf zone edge as a reference. The modeled wave angle obtained from time-averaged field data is indicated by the white arrow

fluid dynamics software Delft3D (Deltares 2011a,b) including wave-current interaction and Stokes drift in all model cases.

The model domain spanned $1250 \mathrm{~m}$ in the alongshore direction and $600 \mathrm{~m}$ in the cross-shore direction, and the depth was based on the collected bathymetry data (Fig. 1B). The beach profile at $Y=$ $0 \mathrm{~m}$, along which the ADCPs were deployed, consisted of a 1/7.6 subaerial beach slope, 1/3 subaqueous beach step, and 1/19 subaqueous beach profile. The model mesh scheme was a regular grid (hexahedral cells) with grid spacing of $10 \mathrm{~m}$ along the beach, approximately 5 to $10 \mathrm{~m}$ in the cross-shore with the finest spacing at the shoreline, and $14 \sigma$-layers representing the depth with a fine mesh near the bed to resolve bottom boundary layer streaming. Cross-shore reflections were controlled by an offshore Riemann boundary, which is a weakly reflective open boundary, and alongshore reflections were suppressed by a weakly reflective water level boundary to the south, while the north side was a closed boundary. Prior to running the larval transport model (details in next subsection), we omitted $50 \mathrm{~m}$ of the northern and $300 \mathrm{~m}$ of the southern ends to eliminate potentially adversely affected boundary currents. A $k-\varepsilon$ closure scheme was used for modeling turbulence by solving turbulent kinetic energy $(k)$ and energy dissipation rate $(\varepsilon)$. Oblique waves with $0.4 \mathrm{~m}$ RMS wave height $\left(H_{\text {rms }}\right)$ and $9.45 \mathrm{~s}$ peak wave period, based on the average wave data during the survey period in the summer of 2011, were generated at the offshore boundary. Wave angles did not vary widely during the survey period, so the time-averaged wave angle $(\theta=$ $36^{\circ}$ relative to true north) was used (Fig. 1B). In addition, $H_{\text {rms }}$ values of 0.2 and $0.8 \mathrm{~m}$, corresponding to approximately the lowest and the highest $H_{\mathrm{rms}}$ observed during the field survey, respectively, were also applied to investigate the effect of wave height on concentrations of detritus and larvae in the surf zone. Imposing either no wind or $8.0 \mathrm{~m} \mathrm{~s}^{-1}$ constant onshore wind tested the effect of wind stress. Offshore winds were ignored because they were rare and weak during our field campaign.

The model was idealized to show a typical larval transport pattern at CRSB using settings following Fujimura et al. (2014). The duration of a model run was $48 \mathrm{~h}$ with a time step of $3 \mathrm{~s}$ and an output interval of $6 \mathrm{~s}$. It was confirmed by monitoring horizontal velocities that all model cases converged within several hours, but we conservatively set the first $24 \mathrm{~h}$ as a spin-up stage, and only the second $24 \mathrm{~h}$ simulation output was used for a larval transport simulation. Stratification, tides, and diurnal wind stresses may add more temporal variability of crossshore larval transport; however, we did not include these variables because our aim was to show the essential forcing for onshore larval transport

\section{Larval transport model}

An individual-based model with the same Lagrangian transport equations as those used by Fujimura et al. (2014) was applied. A random walk coupled with eddy diffusivities from the hydrodynamic model was included to account for subgrid-scale turbulence. The earlier model also suggested that another essential part of the transport mechanism is turbulence-dependent sinking behavior (Fujimura et al. 2014), where competent larvae stop swimming and sink to the bottom at $-10^{-2} \mathrm{~m} \mathrm{~s}^{-1}$ by their own body weight when the turbulent energy dissipation rate is greater than $10^{-5} \mathrm{~m}^{2} \mathrm{~s}^{-3}$ (Fuchs et al. 2004). Note that turbulent dissipation rates exceeding this threshold occur almost everywhere in the surf zone and within the bottom boundary layer. 
Each individual particle was assigned a vertical velocity $(w)$, either $-10^{-3} \mathrm{~m} \mathrm{~s}^{-1}$ or $4 \times 10^{-3} \mathrm{~m} \mathrm{~s}^{-1}$, which represent buoyancy or vertical swimming speed of a competent larva (Fuchs et al. 2004), or $-2.5 \times 10^{-3} \mathrm{~m} \mathrm{~s}^{-1}$, the average sinking velocity of detritus (Shanks et al. 2015). No active horizontal swimming behavior was considered here. In the $24 \mathrm{~h}$ simulation time, 637 particles equally distributed alongshore $(\Delta Y=10 \mathrm{~m})$ or cross-shore $(\Delta X=$ $2.5 \mathrm{~m})$ were released every hour either from offshore $(X=550 \mathrm{~m})$, closer to the shore $(X=350 \mathrm{~m})$, or the north $(Y=350 \mathrm{~m})$. Negatively buoyant particles (detritus and bottom-dwelling larvae) were released near the bottom, and positively buoyant particles (floating larvae) were released near the water surface. The general flow pattern for each physical case was assumed to be stable because wave conditions did not dramatically change and eddies were not observed near model boundary areas during the field survey. Thus, offshore and lateral sides were set as outlet boundaries, i.e. once a particle exits the model domain, it was not taken into account any more. The first $12 \mathrm{~h}$ run (24 to $36 \mathrm{~h}$ of the hydrodynamic model) was used as a spin-up stage for initialization with particles released every hour, and only the simulation from 12 to $24 \mathrm{~h}$ (36 to $48 \mathrm{~h}$ of the hydrodynamic model) was used to calculate the time-averaged number of particles per grid cell. The model cases and parameters are summarized in Table 1. Each case name describes a test condition: $\mathrm{W}$ if onshore wind is included; $\mathrm{S}$ if sinking behavior is included $;-,+$, and D corresponding to negatively and positively buoyant larvae and negatively buoyant detritus, respectively. For example, Case 1.Sconsists of negatively buoyant larvae with sinking behavior that were released during a no wind event.

\section{RESULTS}

\section{No wind case}

Depth- and time-averaged particle concentrations for the 12 no wind cases are shown in Fig. 2. Particles released at $X=550 \mathrm{~m}$ (Cases 1.S-, 2.S+, 3.-, and 4.D) collected in patches outside the surf zone, but only $O(0.01) \%$ of released particles entered the surf zone. $O(1) \%$ of particles released at $X=350 \mathrm{~m}$ (Cases 5.S-, 6.S+, 7.-, and 8.D) reached the surf zone. The differences in particle concentrations within the surf zone between the 2 different initial release locations $(X=$ 550 and $350 \mathrm{~m}$ ) are due to differences in flow patterns between the 2 release locations (Fig. 2A-H).
Table 1. Model cases. Wind is either no wind (no) or onshore wind (yes) $=8.0 \mathrm{~m} \mathrm{~s}^{-1}$. Release location is initial cross-shore $(X)$ or alongshore $(Y)$ position of particles. Sinking is turbulence-dependent sinking behavior of larvae, included (on) or not (off). $w$ is vertical velocity of particles. Each case name describes a test condition: $\mathrm{W}$ if onshore wind is included; $\mathrm{S}$ if the sinking behavior is included; + and - correspond to positive and negative buoyancy of larvae, respectively; and D is detritus, which is also negatively buoyant

\begin{tabular}{|lcccc|}
\hline Case & Wind & $\begin{array}{c}\text { Release } \\
\text { location }(\mathrm{m})\end{array}$ & Sinking & $\begin{array}{c}W \\
\left(\times 10^{-3} \mathrm{~m} \mathrm{~s}^{-1}\right)\end{array}$ \\
\hline 1.S- & no & $X=550$ & on & -1.0 \\
2.S+ & no & $X=550$ & on & 4.0 \\
3.- & no & $X=550$ & off & -1.0 \\
4.D & no & $X=550$ & off & -2.5 \\
5.S- & no & $X=350$ & on & -1.0 \\
6.S+ & no & $X=350$ & on & 4.0 \\
7.- & no & $X=350$ & off & -1.0 \\
8.D & no & $X=350$ & off & -2.5 \\
9.S- & no & $Y=350$ & on & -1.0 \\
10.S+ & no & $Y=350$ & on & 4.0 \\
11.- & no & $Y=350$ & off & -1.0 \\
12.D & no & $Y=350$ & off & -2.5 \\
13.WS- & yes & $X=550$ & on & -1.0 \\
14.WS+ & yes & $X=550$ & on & 4.0 \\
15.W+ & yes & $X=550$ & off & 4.0 \\
16.WD & yes & $X=550$ & off & -2.5 \\
17.WS- & yes & $X=350$ & on & -1.0 \\
18.WS+ & yes & $X=350$ & on & 4.0 \\
19.W+ & yes & $X=350$ & off & 4.0 \\
20.WD & yes & $X=350$ & off & -2.5 \\
21.WS- & yes & $Y=350$ & on & -1.0 \\
22.WS+ & yes & $Y=350$ & on & 4.0 \\
23.W+ & yes & $Y=350$ & off & 4.0 \\
24.WD & yes & $Y=350$ & off & -2.5 \\
& & & & \\
\hline & & & & \\
\hline
\end{tabular}

Particles released at $X=550 \mathrm{~m}$ had a higher probability of exiting the domain by alongshore flows (Fig. 3) before they got to the surf zone edge, suggesting that the influx of particles from the lateral boundaries can be important (Fig. 2I-L).

Water flow circulated in the cove around $(X, Y)=$ $(100 \mathrm{~m}, 200 \mathrm{~m})$ and continued as an alongshore current up to about $Y=-150 \mathrm{~m}$ (Fig. 3) consistent with dye observations at the same location (J. A. Brown et al. unpubl.). The alongshore current was separated from shore and formed an eddy at $(X, Y)=(150 \mathrm{~m}$, $-150 \mathrm{~m})$. There was a relationship between the particle patch distributions of Case 5.S- and the bottom current pattern rather than the surface current as expected for sinking particles (Fig. 3). Particles trapped by eddies resulted in high-concentration patches. Some particle patch locations were common among the model cases (Fig. 2) associated with underlying flow patterns (Fig. 3). 

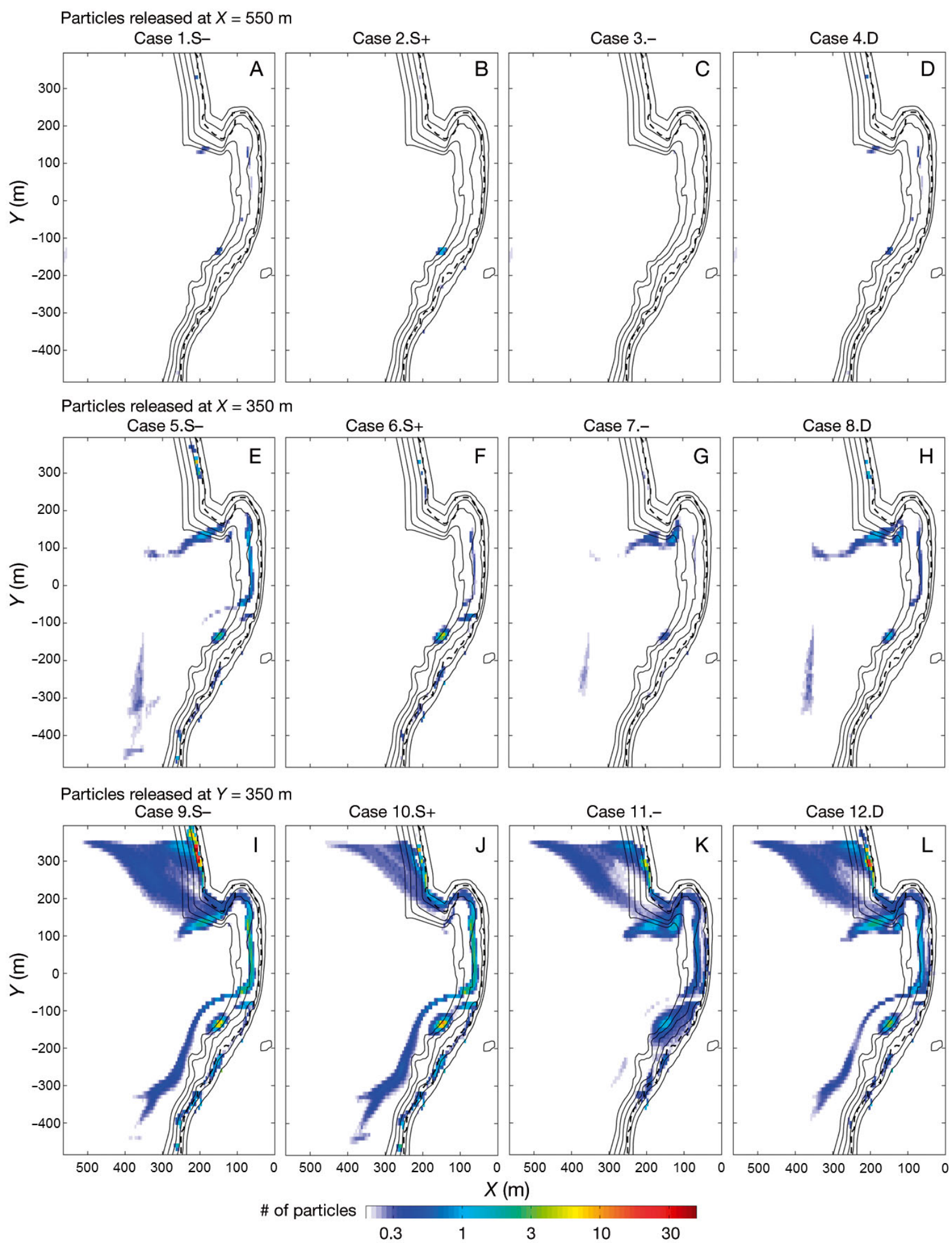

Fig. 2. Depth- and time-averaged number of particles per grid cell in no wind cases. Initial cross-shore particle release positions are $(\mathrm{A}, \mathrm{B}, \mathrm{C}, \mathrm{D}) X=550 \mathrm{~m},(\mathrm{E}, \mathrm{F}, \mathrm{G}, \mathrm{H}) X=350 \mathrm{~m}$, and $(\mathrm{I}, \mathrm{J}, \mathrm{K}, \mathrm{L}) Y=350 \mathrm{~m}$. (A,E,I) Negatively buoyant particles with sinking behavior. $(\mathrm{B}, \mathrm{F}, \mathrm{J})$ Positively buoyant particles with sinking behavior. $(\mathrm{C}, \mathrm{G}, \mathrm{K})$ Negatively buoyant particles without sinking behavior. $(D, H, L)$ Detritus. Bottom contour lines from $0 \mathrm{~m}$ depth (shoreline) to $5 \mathrm{~m}$ depth with $1 \mathrm{~m}$ increments are given as a reference. Black dashed lines are the approximate surf zone edges 


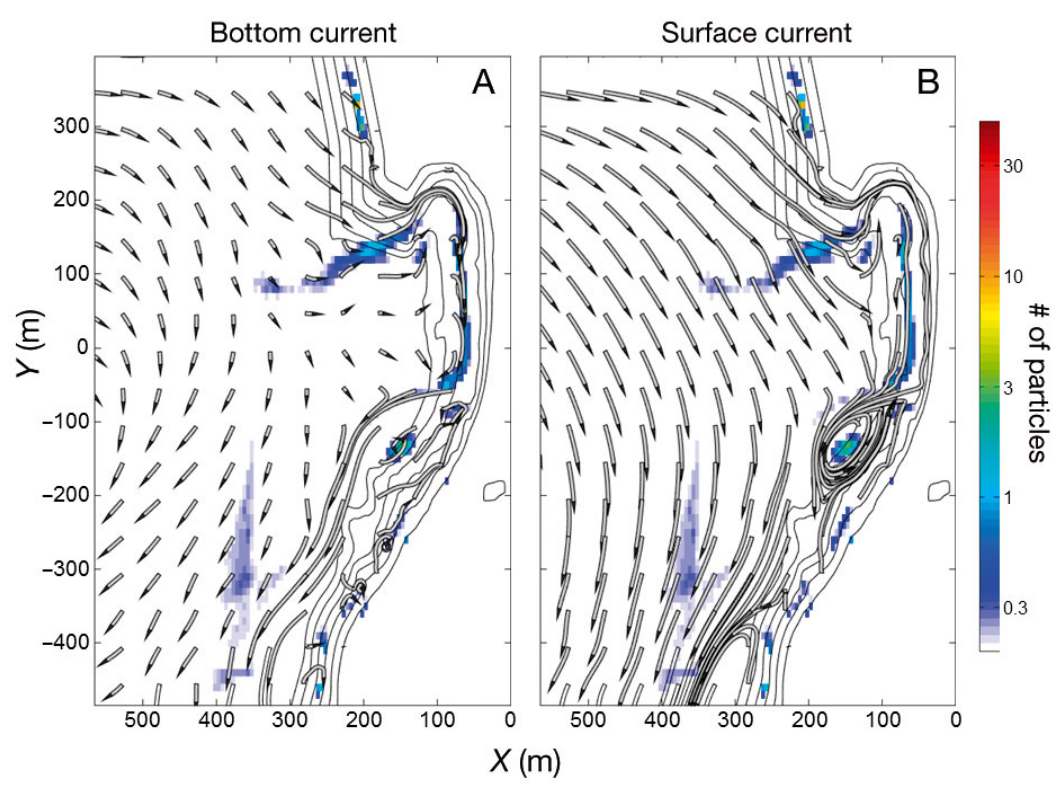

Fig. 3. Trajectories of Lagrangian velocities in no wind condition (A) at the bottom and (B) at the surface with an integration interval of $30 \mathrm{~min}$. Velocity direction is indicated by a black tip. Overlay color map is time- and depthaveraged number of particles in Case 5.S-. Bottom contour lines from $0 \mathrm{~m}$ (shoreline) to $5 \mathrm{~m}$ with $1 \mathrm{~m}$ increments are given alongshore between $Y=-150$ and $-400 \mathrm{~m}$, as seen in Cases14.WS+, 15. W+, 18. WS+, and 19. W+, seemed to be forced by cross-shore currents (Fig. 5). Particle patches in this region were also related to eddies.

\section{Effect of wave height}

Lower and higher wave heights were applied to Cases 5.S-, 8.D, and 18.WS+, which represent successful onshore transport patterns (Fig. 6). Note that the width of the surf zone narrowed or widened as surf zone wave height became smaller with $H_{\text {rms }}=0.2 \mathrm{~m}$ or larger with $H_{\mathrm{rms}}=$ $0.8 \mathrm{~m}$, respectively. Currents were weak and several small eddies $[O(10) \mathrm{m}]$ were formed very close to the shore in the case with $H_{\text {rms }}=$ $0.2 \mathrm{~m}$, which led to relatively high concentrations of particles in the surf zone (Fig. 7A,B). Higher waves $\left(H_{\text {rms }}\right.$

\section{Onshore wind case}

Fig. 4 shows the depth- and time-averaged particle densities for the onshore wind case at CRSB. Negatively buoyant particles with sinking behavior and detritus released at $X=550$ and $350 \mathrm{~m}$ (Cases 13.WS-, 16.WD, 17.WS-, and 20.WD) did not enter the surf zone. The wind-driven surface currents altered the bottom currents from onshore to offshore (Fig. 5A), and the particles were thus flushed offshore.

Similar to the no wind case, water flow circulated in the cove first, formed an alongshore current, and then detached from the shore (Fig. 5). The flow eventually formed a large eddy at $(X, Y)=(250 \mathrm{~m}, 0 \mathrm{~m})$, but particles were not associated with this eddy.

Sinking behavior might not be important for floating particles to settle. Unlike negatively buoyant particles in the no wind case, positively buoyant particles reached the surf zone regardless of sinking behavior. This was mainly because the alongshore current carried more floating particles (Case 23.W+) than sinking particles (Case 22.WS+). Note that the focus is on particles within the surf zone; particles concentrated from $Y=200$ to $-100 \mathrm{~m}$ were outside the surf zone. Positively buoyant particles with sinking behavior tended to disperse and stayed in the north (Fig. 4J). However, particle concentrations $=0.8 \mathrm{~m})$ produced fewer eddies $[O(100) \mathrm{m}]$ and stronger currents that flushed most of the particles from the domain through the southern boundary (Fig. 7C,D).

Adding onshore wind changed the flow patterns, as a few eddies can be seen outside the surf zone, and the large eddy seen in the medium wave height case (Fig. 5B) lost its shape under the low wave condition (Fig. 7B). Directions of the surface currents in the high wave regime were along with the direction of wave propagation rather than wind (Fig. 7D), and thus the effect of onshore wind on the surface seemed to be smaller in the high wave case than the other cases.

Concentrations of modeled larvae (Cases 5.S- and 18.WS+) and detritus (Case 8.D) in the surf zone with alongshore range of $Y= \pm 100 \mathrm{~m}$ were negatively correlated with wave height (Fig. 8; correlation $\mathrm{r}=$ $-0.986,-0.969$, and -0.970 for Cases 5.S-, 8.D, and 18.WS+, respectively). This result is consistent with Shanks et al. (2015), whose sampling site was at about $(X, Y)=(50 \mathrm{~m}, 0 \mathrm{~m})$.

\section{DISCUSSION}

Results of the simulations with larvae released offshore showed that negatively buoyant larvae were 

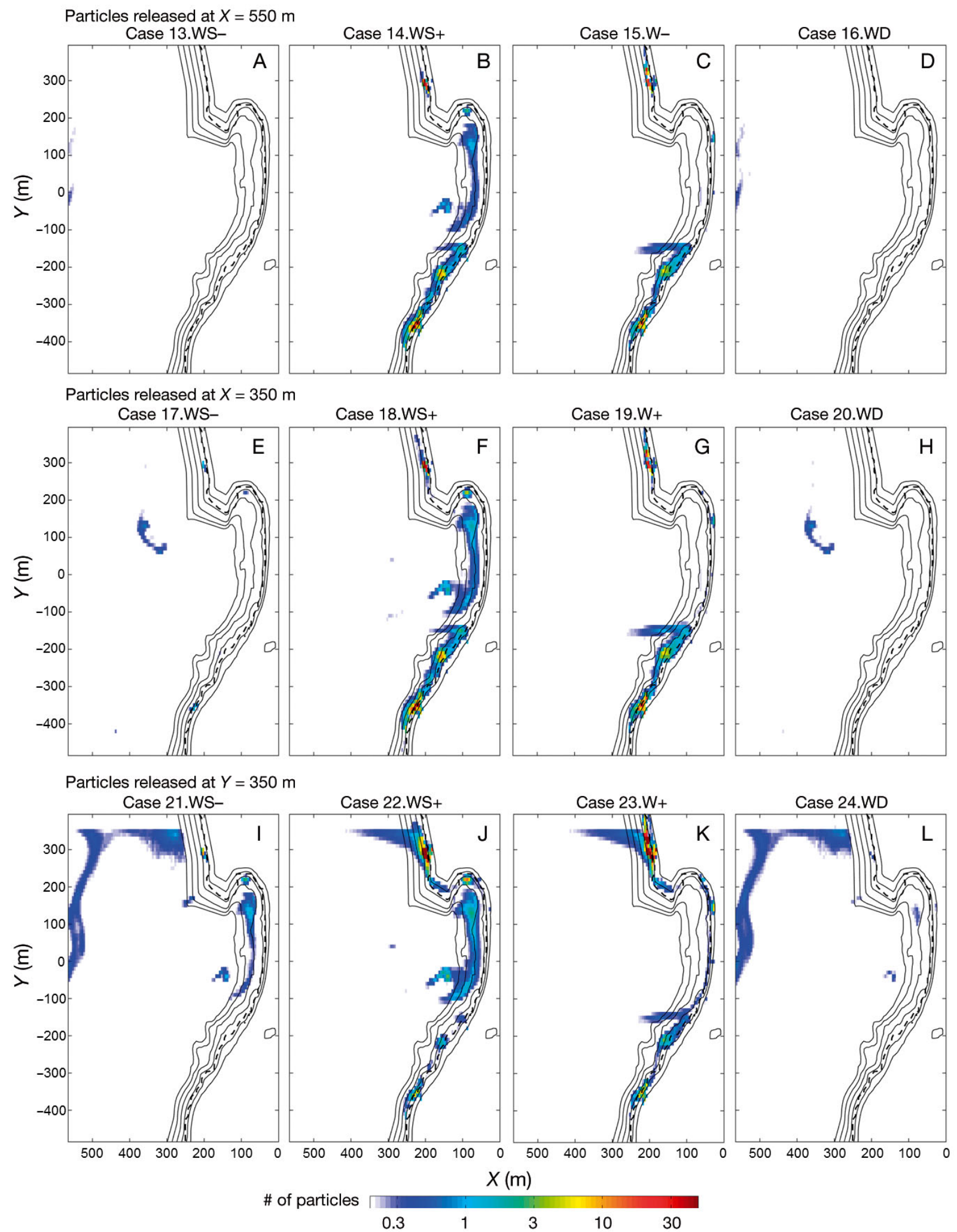

Fig. 4. Depth- and time-averaged number of particles per grid cell in onshore wind cases. Initial cross-shore particle release positions are $(\mathrm{A}, \mathrm{B}, \mathrm{C}, \mathrm{D}) X=550 \mathrm{~m},(\mathrm{E}, \mathrm{F}, \mathrm{G}, \mathrm{H}) X=350 \mathrm{~m}$, and $(\mathrm{I}, \mathrm{J}, \mathrm{K}, \mathrm{L}) Y=350 \mathrm{~m}$. $(\mathrm{A}, \mathrm{E}, \mathrm{I})$ Negatively buoyant particles with sinking behavior. $(B, F, J)$ Positively buoyant particles with sinking behavior. $(C, G, K)$ Positively buoyant particles without sinking behavior. $(\mathrm{D}, \mathrm{H}, \mathrm{L})$ Detritus. Bottom contour lines from $0 \mathrm{~m}$ depth (shoreline) to $5 \mathrm{~m}$ depth with $1 \mathrm{~m}$ increments are given as a reference. Black dashed lines are the approximate surf zone edges 

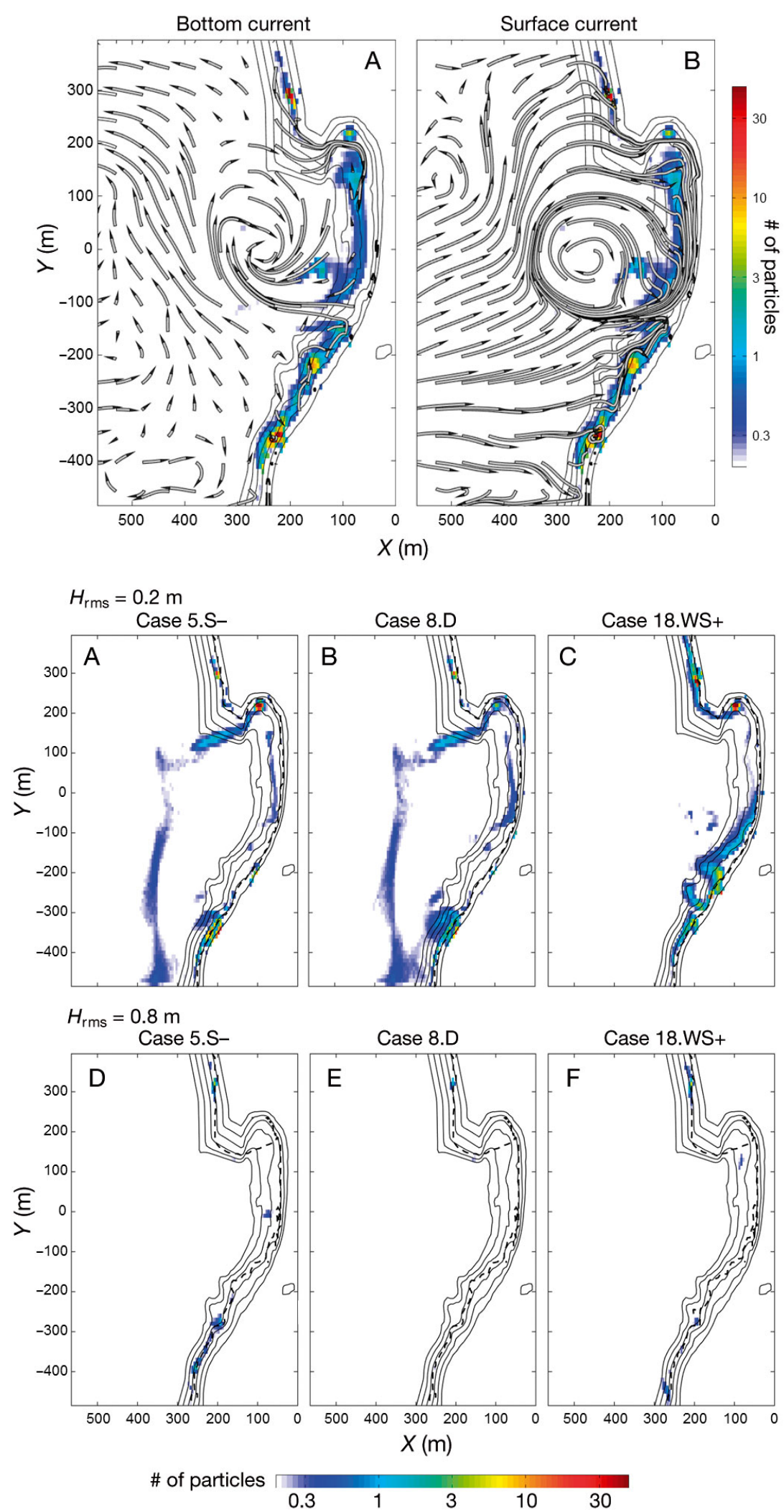

Fig. 6. Subcases of Cases 5.S-, 8.D, and 18.WS+. (A,B,C) $H_{\mathrm{rms}}=0.2 \mathrm{~m},(\mathrm{D}, \mathrm{E}, \mathrm{F})$ $H_{\mathrm{rms}}=0.8 \mathrm{~m}$. Note that the approximate surf zone edge indicated by a black dashed line changed with wave height. $H_{\mathrm{rms}}$ : RMS wave height
Fig. 5. Trajectories of Lagrangian velocities in onshore wind condition (A) at the bottom and (B) at the surface with an integration interval of $30 \mathrm{~min}$. Velocity direction is indicated by a black tip. Overlay color map is time- and depth-averaged number of particles in Case 18.WS+. Bottom contour lines from $0 \mathrm{~m}$ (shoreline) to $5 \mathrm{~m}$ with $1 \mathrm{~m}$ increments are given

carried onshore by bottom currents, while positively buoyant larvae were transported onshore by wind-driven surface currents, which is consistent with Fujimura et al. (2014); however, the alongshore current and associated eddies also played important roles in the distribution of larvae at CRSB. Thus, larvae were also released from upstream of the alongshore current (i.e. north). It appeared that larvae were transported by the alongshore current and trapped by eddies, owing to an interaction between the current and shore, forming patches of larvae. Wave height changed both the size and location of eddies as well as general flow directions; hence, it is also an important factor in larval transport.

The concentration of detritus was correlated with the concentration of negatively buoyant particles, and this result is also consistent with the field study (Shanks et al. 2015). Detritus thus can be used as a supplemental tool to track competent larvae (e.g. barnacle cyprids) and detritusassociated organisms (e.g. harpacticoid copepods), whereas plankton may move either upward or downward (Mileikovsky 1973, Chia et al. 1984). Navarrete et al. (2015) suggested that competent mussel larvae, which are dense and tend to sink to the bottom, can be transported onshore through the surf zone by bottom currents (i.e. streaming). Their proposed mechanism is consistent with our model cases showing that negatively buoyant particles were transported via streaming under the no wind condition. Organisms near 


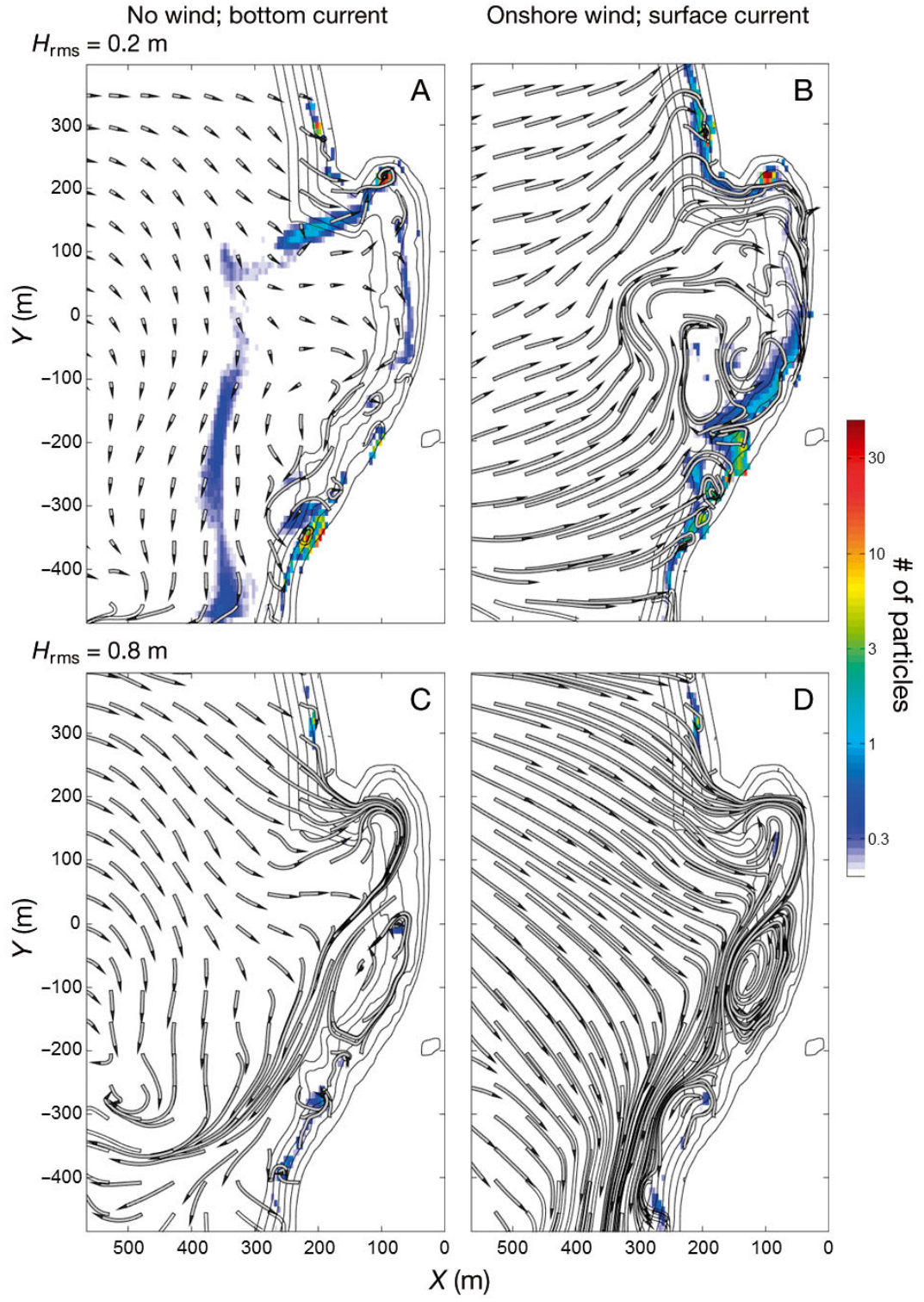

Fig. 7. Trajectories of Lagrangian velocities $(A, C)$ at the bottom in no wind condition and $(B, D)$ at the surface in onshore wind condition with an integration interval of $30 \mathrm{~min}$. Velocity direction is indicated by a black tip. Overlay color map is time- and depth-averaged number of particles in subcases of $(\mathrm{A}, \mathrm{C})$ Case 5.S- and $(\mathrm{B}, \mathrm{D})$ Case 18.WS+ with $(\mathrm{A}, \mathrm{B}) H_{\mathrm{rms}}=0.2 \mathrm{~m},(\mathrm{C}, \mathrm{D})$ $H_{\text {rms }}=0.8 \mathrm{~m}$. Bottom contour lines from $0 \mathrm{~m}$ (shoreline) to $5 \mathrm{~m}$ with $1 \mathrm{~m}$ increments are given. $H_{\mathrm{rms}}$ : RMS wave height

the surface or in the upper water column probably reach the shore when the onshore wind is strong enough. To investigate further transport and distribution patterns of each taxa, it might be necessary to collect data of vertical distributions of target organisms and their characteristics, especially buoyancies, as well as correlations with local wave and wind data.

Smaller wave heights enable competent larvae and detritus to enter the surf zone, as the field data show (Shanks et al. 2015), whereas higher waves flushed the particles via the strong alongshore current. Note that the settlement of larvae should be more easily accomplished with smaller waves, not only because of the high rate of onshore transport, but also because the low energy and low turbulence may enable them to settle on a substrate.

Other possible physical factors influencing cross-shore exchange that

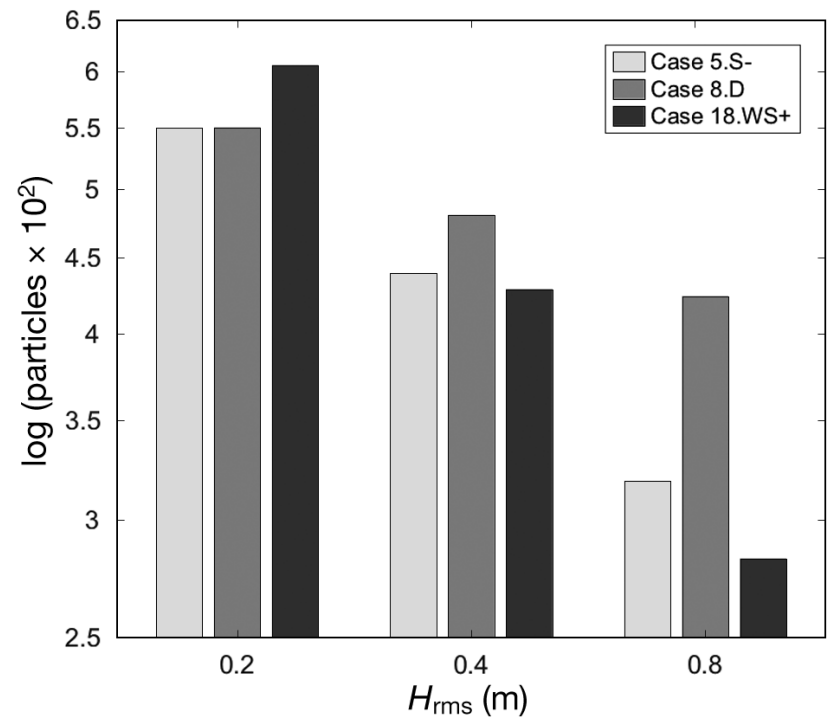
were not included in the current model are the breaking wave roller and wave reflection. Breakinginduced rollers can entrain some particles and carry them to the shore, thereby contributing to onshore particle transport (Feddersen 2007, Reniers et al. 2013). This study focused on the mechanisms enabling larvae to enter the surf zone, but larvae may use additional forcing at the final moment to settle in the intertidal zone. The other wave characteristic ignored in our model is wave reflection, which is high at steep beaches (Battjes 1974). According to the field study by Shanks et al. (2015), approximately $30 \%$ of wave energy was reflected offshore in our cases; how-

Fig. 8. Time-averaged number of particles in the surf zone with alongshore range of $Y= \pm 100 \mathrm{~m}$ in $3 H_{\text {rms }}$ subcases 
ever, the reflection did not largely affect the mean flow for onshore particle transport. Our results on particle concentrations inside and outside the surf zone are consistent with Shanks et al. (2015), suggesting that the effects of these factors could be negligible in our cases.

We found common particle transport patterns among cases when particles entered the surf zone for both wind regimes. Particles concentrated on the middle part of the shore were largely affected by the alongshore current. While particles were distributed by the alongshore current, nearshore eddies accumulated these particles, resulting in high particle concentration patches. Negatively buoyant particles that reached the northern shore were delivered by bottom boundary layer streaming, and positively buoyant particles that reached the northern and the southern shores were carried by wind-driven surface currents. These are similar to the transport mechanisms in the previous model application at a gently sloping rip-channeled beach (Fujimura et al. 2014).

As we mentioned, offshore wind was ignored because it was weak and rare during the fieldwork, and even if a fairly strong offshore wind blows, we expect that current patterns affecting larval transport would be similar to the no wind case with enhanced streaming due to wind-driven offshore currents. Nonetheless, the nearshore eddies might shift slightly offshore, and distribution patterns of particles would probably differ from the performed model cases.

Effects of particle buoyancy and sinking behavior for ingress into the surf zone at CRSB without wind forcing seemed to be less important than in the model cases with the same conditions at the gently sloping rip-channeled beach simulated by Fujimura et al. (2014). The rate of particles entering the surf zone at CRSB was much lower than that at the gently sloping rip-channeled beach, consistent with related field data and simulations (Morgan et al. 2016, 2017). Our result is also consistent with the previous finding that recruitment of intertidal invertebrate larvae was higher at more dissipative than at more reflective beaches (Shanks et al. 2010, 2017). However, differences between these 2 beaches are not limited to slopes, as these beaches both have alongshore variability at different scales. CRSB is a pocket beach and the headlands span $O(1000) \mathrm{m}$, whereas the gently sloping beach has rip channels spacing at $O(100) \mathrm{m}$. The complexity of these beaches needs to be decomposed into beach steepness and alongshore variability to definitively establish that rates of larval delivery are higher at more dissipative than at more reflective surf zones. Alongshore variability may in- crease larval retention rates inside the surf zone by enhancing the formation of eddies, which is discussed below.

CRSB is a steep pocket beach with oblique waves, resulting in a southward alongshore current that eventually disconnects from the surf zone to form an offshore flow. The alongshore current is accompanied by an onshore flow further to the south. Onshore migrating particles initially followed these main currents and then were trapped by local eddies, eventually forming high-concentration patches. Smaller eddies formed closer to shore with smaller waves, resulting in high larval and detrital concentrations in the surf zone. In contrast, larger waves induced larger and fewer eddies predominantly outside the surf zone, and consequently far fewer larvae and detritus particles entered and stayed in the surf zone. Larvae trapped by eddies in a more dissipative surf zone were also modeled by Fujimura et al. (2014), although the eddies were formed by rip channels. Likewise, the rip current eddies accumulate phytoplankton, leading to high cell concentrations in the surf zone (Talbot \& Bate 1987). Furthermore, MacMahan et al. (2010) observed the surf zone eddies retained a majority of released drifters, indicating those eddies may contribute to high concentrations of dispersing materials in the surf zone. Larval concentrations in the surf zone were reduced with larger waves, consistent with Shanks et al. (2015), due to the strong alongshore current as mentioned earlier in this section. Additionally, the eddies formed by large waves are outside the surf zone, concentrating larvae away from the surf zone. Larvae may generally tend to reach shore for settlement during small wave events, but studies at other shores are required to confirm this hypothesis.

Acknowledgements. This study was supported by the National Science Foundation (OCE092735) project 'Collaborative research: Does coupling between the inner shelf and surf zone regulate larval supply to intertidal populations?' We appreciate our colleagues, technicians, and students who helped with the field work. C.B.P. is funded by the National Science Foundation (OCE 1155698). This research is a contribution of the Rosenstiel School of Marine and Atmospheric Science, the Oregon Institute of Marine Biology, the Naval Postgraduate School, and the Bodega Marine Laboratory.

\section{LITERATURE CITED}

Battjes JA (1974) Surf similarity. Coast Eng 1:466-479

Butman CA (1987) Larval settlement of soft-sediment invertebrates: the spatial scales of pattern explained by active habitat selection and the emerging role of hydrodynamical processes. Oceanogr Mar Biol Annu Rev 25:113-165 
Butman CA (1990) Sediment trap experiments on the importance of hydrodynamical processes in distributing settling invertebrate larvae in near-bottom waters. J Exp Mar Biol Ecol 134:37-88

Chia FS, Buckland-Nicks J, Young CM (1984) Locomotion of marine invertebrates: a review. Can J Zool 62: 1205-1222

Deltares (2011a) Delft3D-FLOW user manual. Version 3.15. Deltares, Delft

Deltares (2011b) Delft3D-WAVE user manual. Version 3.04. Deltares, Delft

Denny MW, Shibata MF (1989) Consequences of surf-zone turbulence for settlement and external fertilization. Am Nat 134:859-889

Feddersen F (2007) Breaking wave induced cross-shore tracer dispersion in the surf zone: model results and scalings. J Geophys Res 112:C09012

Fuchs HL, Mullineaux LS, Solow AR (2004) Sinking behavior of gastropod larvae (Ilyanassa obsoleta) in turbulence. Limnol Oceanogr 49:1937-1948

Fuchs HL, Huter EJ, Schmitt EL, Guazzo RA (2013) Active downward propulsion by oyster larvae in turbulence. J Exp Biol 216:1458-1469

Fujimura AG, Reniers AJHM, Paris CB, Shanks AL, MacMahan JH, Morgan SG (2014) Numerical simulations of larval transport into the surf zone. Limnol Oceanogr 59: 1434-1447

Longuet-Higgins MS (1953) Mass transport in water waves. Phi Trans R Soc A 245:535-581

MacMahan JH, Brown J, Brown J, Thornton EB and others (2010) Mean Lagrangian flow behavior on an open coast rip-channeled beach: a new perspective. Mar Geol 268: $1-15$

Mileikovsky SA (1973) Speed of active movement of pelagic larvae of marine bottom invertebrates and their ability to regulate their vertical position. Mar Biol 23:11-17

Morgan SG, Shanks AL, Fujimura AG, Reniers AJHM and others (2016) Surfzone hydrodynamics as a key determinant of spatial variation in rocky intertidal communities. Proc R Soc B 283:20161017

Morgan SG, Shanks AL, MacMahan J, Reniers AJHM and

Editorial responsibility: Paul Snelgrove,

St. John's, Newfoundland and Labrador, Canada others (2017) Surf zones regulate larval supply and zooplankton subsidies to nearshore communities. Limnol Oceanogr, doi:10.1002/lno.10609

* Navarrete SA, Largier JL, Vera G, Tapia FJ and others (2015) Tumbling under the surf: wave-modulated settlement of intertidal mussels and the continuous settlement-relocation model. Mar Ecol Prog Ser 520:101-121

Queiroga H, Blanton J (2004) Interactions between behavior and physical forcing in the control of horizontal transport of decapod crustacean larvae. Adv Mar Biol 47:107-214

Reniers AJHM, MacMahan JH, Beron-Vera FJ, Olascoaga MJ (2010) Rip-current pulses tied to Lagrangian coherent structures. Geophys Res Lett 37:L05605

Reniers AJHM, Gallagher EL, MacMahan JH, Brown JA, van Rooijen AA, van Thiel de Vries JSM, van Prooijen BC (2013) Observations and modeling of steep-beach grain-size variability. J Geophys Res 118:577-591

Rilov G, Dudas SE, Menge BA, Grantham BA, Lubchenco J, Schiel DR (2008) The surf zone: a semi-permeable barrier to onshore recruitment of invertebrate larvae? J Exp Mar Biol Ecol 361:59-74

Roy A, Metaxas A, Ross T (2012) Swimming patterns of larval Strongylocentrotus droebachiensis in turbulence in the laboratory. Mar Ecol Prog Ser 453:117-127

* Shanks AL, Morgan SG, MacMahan J, Reniers AJHM (2010) Surf zone physical and morphological regime as determinants of temporal and spatial variation in larval recruitment. J Exp Mar Biol Ecol 392:140-150

Shanks AL, MacMahan J, Morgan SG, Reniers AJHM and others (2015) Transport of larvae and detritus across the surf zone of a steep reflective pocket beach. Mar Ecol Prog Ser 528:71-86

Shanks AL, Morgan SG, MacMahan J, Reniers AJHM (2017) Alongshore variation in barnacle populations is determined by surfzone hydrodynamics. Ecol Monogr 87:508-532

Stokes GG (1847) On the theory of oscillatory waves. Trans Camb Philos Soc 8:441-455

Talbot MMB, Bate GC (1987) The spatial dynamics of surf diatom patches in a medium energy, cuspate beach. Bot Mar 30:459-465

Submitted: June 22, 2015; Accepted: September 6, 2017 Proofs received from author(s): October 17, 2017 